\title{
Tindakan Pemerintah Daerah Memberikan Perlindungan Hukum Terhadap Suku Anak Dalam Yang Mengemis Di Kota Jambi.
}

\author{
Latifah Amir, Dhil's Noviades, Netty \\ Fakultas Hukum, Universitas Jambi, Indonesia
}

\begin{abstract}
ABSTRAK
Suku Anak Dalam disingkat dengan SAD merupakan istilah yang diberikan di Provinsi Jambi yang diberikan kepada anak rimba. Dimana SAD ini mempunyai kehidupan yang berbeda dengan kehidupan manusia biasa, cara kehidupan mereka adalah nomaden ( tidak tetap) mereka mempunyai pola kehidupan yang berpindah pindah dari satu tempat ke tempat yang lain dalam hutan dengan system perambahan hutan. Dengan berubahnya fungsi hutan pada saat ni maka kehidupan mereka sudah mulai terancam kareana hutan sebagai sumber kehidupan mereka sudah berubah menjadi hutan produksi. Dimana hutan produksi ini lebih menguntungkan pengelola. Dengan kondisi tersebut SAD sudah susah mencari sumber kehidupan terutama untuk kebutuhan makanannya. Pada saat ini SAD sudah mulai keluar dari hutan untuk mencari makan tetapi setelah mereka berbaur dengan kehidupan masyarakat biasa mereka tidak mampu untuk bekerja selain menjadi pengemis untuk memenuhi kebutuhan terutama untuk makan. Melihat kondisi seperti ini sangat memprihatinkan dimana pemerintah baik pusat maupun daerah harus tanggap dan tidak membiarkan mereka terlantar seperti ini. Tujuan penelitian adalah untuk mengetahui sejauh mana tindakan yang di lakukan oleh pemerintah terutama pemerintah daerah dalam memberikan perlindungan hokum terhadap SAD. Dan dari hasil penelitian ini diharapkan bias memberika kontribusi positif terhadap pemerintah daerah sebagi bahan pengkajian untuk membuat kebijakan perlindungan hokum terhadap suku anak dalam.
\end{abstract}

Kata Kunci : Perlindungan Hukum, Suku Anak Dalam.

\section{PENDAHULUAN}

Otonomi daerah telah membawa berbagai perubahan mendasar dalam kehidupan bermasyarakat, sehingga peran, tugas dan fungsi lembaga-lembaga pemerinah daerah dituntut mencegah segala perubahan tersebut dan sehingga peran, tugas, fungsi lembaga itu seringkali belum dipahami dalam peraturan pemerintahan daerah satu kerja tim dengan yang satu sama lainnya saling mempengaruhi.

Sebagai konsep negara kesejahteraan dalam hal ini hukum administrasi menjadi bagian dalam kegiatan pemerintahan. Pengertian hukum administrasi negara bukanlah satu-satunya cara untuk menjelaskan konsep hukum administrasi negara, namun demikian sebagai pegangan pengertian hukum administrasi negara dapat dikemukakan dari beberapa pendapat para ahli, salah satunya J. Oppenheim yaitu hukum administrasi negara ialah keseluruhan aturan-aturan hukum yang harus 
diperhatikan alat perlengkapan negara dan pemerintah jika menjalankan kekuasaannya. ${ }^{1}$

Menurut Juniarso \& Achmad Sodik Sudrajat Menyatakan :

"Kedudukan dan peran Pemerintah Daerah sangat strategis karena menjadi pondasi dari struktur pemerintahan di Indonesia dalam rangka mewujudkan kesejahteraan rakyat.

Penjelasan umum UU No 23 Tahun 2014 Tentang Pemerintah Daerah pengganti UU No 32 Tahun 2004, menyatakan, sebagaimana diamanatkan UUD 1945 terdapat urusan pemerintah yang sepenuhnya menjadi kewenangan urusan pemerintah pusat yang dikenal dengan urusan pemerintahan absolut dan ada urusan pemerintahan konkuren. Urusan pemerintahan yang konkuren yaitu urusan pemerintahan wajib dan urusan pemerintahan pilihan yang dibagi antara Pemerintah Pusat, Daerah provinsi dan daerah kabupaten/kota.

Suku Anak Dalam (SAD) adalah salah satu suku yang masih menerapkan pola hidup mengikuti ajaran para leluhurnya, dan memilih untuk hidup dari segala sesuatu yang berada di alam. Hal inilah yang menyebabkan masyarakat SAD dikenal sebagai suku terasing karena kehidupannya yang seolah mengasingkan diri dari modernisasi yang sedang berkembang dengan seluruh kemajuan tekhnologi dan peradaban kemanusiaannya.

Penyebutan Suku Anak Dalam (SAD) adalah istilah yang diberikan oleh Pemerintah dengan latar belakang keberadaan masyarakat ini yang sebagian besar hidup secara nomaden di kawasan hutan-hutan di Sumatra khususnya Jambi dan sebagian wilayah Sumatera Selatan dan untuk membedakannya dengan masyarakat yang hidup di luar hutan dengan istilah "orang terang". Istilah ini dipergunakan untuk mengganti penamaan masyarakat dengan istilah "suku Kubu" yang bertendensi pada makna pelecehan karakter masyarakat SAD sebagai masyarakat yang terbelakang. Namun masyarakat SAD iu sendiri lebih memilih untuk menyebut dirinya dengan "orang Rimba" yang berarti manusia-manusia yang hidup dan tinggal di dalam hutan².

Suku Anak Dalam adalah salah satu dari beberapa suku minoritas di Indonesia yang masih hidup dalam pola tradisional dan nyaris tidak bersentuhan dengan perkembangan peradaban tekhnologi dan ilmu pengetahuan. Kehidupan masyarakat SAD yang bergantung pada alam dan lingkungan sekitarnya, saat ini semakin memprihatinkan dengan semakin menyempitnya wilayah hutan yang menjadi area kehidupan mereka, tergerus oleh keberadaan hutan kawasan industri maupun karena semakin meluasnya kerusakan hutan sebagai akibat pembalakan liar dan pembakaran

\footnotetext{
Mas, 1986),hlm.9

2 Diakses dari laman http://takaitu.com/suku-anak-suku-minoritas-hidup-pulau-sumatera tanggal 7 Februari 2018
}

1 E. Utrecht, Pengantar Hukum Administrasi Negara Indonesia,(Surabaya: Pustaka Tinta 
lahan di sekitar wilayah hutan. Kondisi ini akan memberikan dampak negatif berkelanjutan terhadap kekayaan alam yang selama ini menjadi bagian dari budaya masyarakat SAD yakni kemampuan meramu dan mengolah tanaman-tanaman berkhasiat obat menjadi obat-obatan tradisional.

Ketergantungan pada alam dan pola hidup nomaden yang masih dijalani sebagian besar masyarakat SAD menuntut adanya ketahanan fisik dalam mengatasi alam. Salah satunya adalah dengan mengembangkan kemampuan mengidentifikasi dan mengolah tanaman-tanaman di sekitar mereka menjadi sumber obat-obatan tradisional yang tidak ternilai harganya. Kemampuan inilah yang ditenggarai akan mengalami penurunan bahkan dapat menghilang sama sekali apabila wilayah hutan dan alam di lingkungan masyarakat SAD bertempat tinggal tidak dapat dijaga kelestariannya. Oleh karena itu diperlukan berbagai kebijakan hukum yang dapat melindungi ketahanan dan kemampuan masyarakat SAD dalam melanjutkan kehidupan, sekaligus sebagai bagian dari upaya perlindungan dan pemenuhan hakhak konstitusional SAD sebagai warga negara Indonesia, antara lain hak setiap orang untuk hidup sejahtera lahir dan batin, bertempat tinggal dan mendapatkan lingkungan hidup yang baik dan sehat serta berhak memperoleh pelayanan kesehatan (Pasal 28 H ayat (1) UUD 1945).

Pasal 34 UUD 1945 , mengatur bahwa fakir miskin dan anak terlantar di pelihara oleh Negara dan Negara juga bertanggungjawab atas penyediaan fasilitas pelayanan kesehatan dan fasilitas pelayanan umum yang layak. Secara konstitusinal bahawa sudah ada jaminan oleh Negara untuk memelihara dan mengayomi masyarakat miskin dan terlantar.

Karena susah nya untuk mencari kehidupann untuk memenuhi kebutuhan hidup SAD sehinggga mereka terpaksa pergi keluar wilayah hutan untuk mencari makan karena yang dibutuhkan mereka adalah bagaimana mereka bisa memenuhi kebutuhan hidupnya sehari hari mereka pergi ke kota termasuk kota jambi sebagai wialayah tempat pencarian nafkah mereka sehingga di Kota jambi berkeliaran SAD yang tidurnya pada malam hari di depan emperan pertokoan dan untu memenuhi kebutuhan hidup untuk makan mereka terpaksa mengemis itupun kalau diberi oleh masyarakat kalau tidak dapat rezki tentu mereka harus menahan lapar. Pemandangan seperti ini sangat menyedihkan sekarang pertanyaan yang muncul bagaimana tindakan yang di lakukan pemerintah daerah melihat suaana seperti ini.

Kalau di lihat dari kehidupan suku anak dalam bahwa mereka termasuk golongan sebagaimana yang dimaksudkan dalam pasal 34 UUD 1945 dan kewajiban dan tanggungajawab Negara untuk melindunginya dari segala kehidupan atau hak mereka.

Berdasarkan apa yang telah diuraikan pada latar belakang masalah, maka yang menjadi permasalahan dalam penelitian ini adalah: 
1. Bagaimana sejarah adanya Suku Anak Dalam di Provinsi Jambi

2. Bagaimana tindakan Pemerintah Daerah dalam memberikan perlindungan Hukum terhadap Suku Anak Dalam yang berkeliaran di Kota jambi.

\section{METODE PENELITIAN}

\section{Jenis Penelitian}

Adapun tipe penelitian yang digunakan dalam penelitian ini ialah Yuridis Empiris. Yaitu penelitian yang menganalisa atau mengkaji tindakan yang dilakukan oleh pemerintah daerah baik Pemerintah Provinsi Jambi maupun Kota Jambi dalam rangka melindungi hak hak Suku Anak Dalam yang suka mengemis di Kota jambi

\section{Spesifikasi Penelititian}

Penelitian ini bersifat deskriptif, dari hasil penelitian menggambarkan tindakan pemerintah Daerah yaitu Pemerintah Daerah yang diberi kewenangan baik Propinsi maupun Kota Jambi dalam memberikan peerlindunan hokum terhadap Suku Anak Dalam , baik berupa tindakan hukum maupun yang bukan tindakan hukum. Tindakan hokum pemerintah daerah akan memberikan kewenangan kepada lembaga mana dalam memberikan perlindungan kepada suku anak dalam yang berkeliaran di Kota Jambi..

\section{Teknik Pengumpulan Data}

Data penelitian dikumpulkan dengan cara wawancara, yaitu tanya jawab baik secara tertutup maupun terbuka dengan para informan yang sudah ditentukan yang ada hubungannnya dengan penelitian ini antara lain. Selain itu, peneliti juga mempelajari kejadian-kejadian atau kasus-kasus yang terjadi berkaitan dengan judul serta masalah yang sedang diteliti dikaitkan peraturan yang mengatur dalam penelitian ini.

\section{Analisis Data.}

Setelah data dikumpulkan dengan lengkap, tahapan berikutnya adalah tahap analisa data. Pada tahap ini data akan diolah sedemikian rupa sehingga diperoleh kebenarankebenaran yang dipakai untuk menjawab persoalan yang diajukkan dalam penelitian. Setelah jenis data dikumpulkan maka analisa data dalam penulisan ini adalah bersifat kualitatif, yaitu suatu bentuk analisa yang mempertegas, memperpendek, membuat fokus, membuang hal yang tidak penting dan mengatur sedemikian rupa sehingga kesimpulan akhir dapat dilakukan. Serta peneliti akan mengerti apa yang terjadi dan memungkinkan untuk mengerjakan sesuatu pada analisis ataupun tindakkan lain berdasarkan pengertian tersebut. 


\section{PEMBAHASAN}

\section{Sejarah Suku Anak Dalam di Provinsi Jambi}

Suku Anak Dalam merupanakan salah satu Komunitas Adat Terpencil (KAT) yang ada di Provinsi Jambi yang mempunyai permasalahan spesifik, jika kita melihat pola kehidupan dan penghidupan mereka, hal ini disebabkan oleh keterikatan adat istiadat yang begitu kuat, hidup berkelompok dengan pakaian hanya sebagian menutup badan dengan kata lain mereka sangat tergantung dengan hasil hutan / alam dan binatang buruan.

Suku Anak Dalam ini juga disebut Orang Kubu .Pengertian Kubu sendiri dalam bahasa melayu Jambi berarti tempat persembunyian atau "Bodoh" nama ini berasal dari adanya desa yang bernama "Kubu Kandang" dan "Pangabuan" yang berada ditepi sungai Batang Hari. Kemungkinan desa-desa tersebut merupakan perkampungan awal mereka. ${ }^{3}$

Pengertian Kubu yang berarti bodoh sangat tidak enak didengar, karena ada kesan merendahkan, oleh karena itu mereka enggan disebut sebagai Orang Kubu, mereka lebih suka disebut dirinya sebagai "Suku Anak Dalam", Orang rimbo atau “Orang Kelam" sedangkan orang desa disekitarnya disebut "Orang Terang". ${ }^{4}$

Penyebutan terhadap Orang Rimba perlu untuk diketahui terlebih dahulu, karena ada tiga sebutan terhadap dirinya yang mengandung makna berbeda, yaitu :

1. KUBU; merupakan sebutan yang paling popular digunakan, terutama oleh orang Melayu dan masyarakat internasional. Kubu dalam bahasa Melayu memiliki makna peyorasi seperti primitive, bodoh, kafir, kotor dan menjijikan. Sebutan kubu telah terlanjur populer terutama oleh berbagai tulisan pegawai colonial dan etnografer pada awal abad ini.

2. SUKU ANAK DALAM; sebutan ini digunakan oleh Pemerintah melalui Derpartemen Sosiasl. Anak Dalam memiliki makna orang terbelakang yang tinggal dipedalaman, karena itu dalam perspektif pemerintah mereka harus dimodernisasikan dengan mengeluarkan mereka dari hutan dan dimukimkan melalui program pemberdayaan KAT.

3. ORANG RIMBA; adalah sebutan yang digunakan oleh etnik ini yang menyebut dirinya. Makna tersebut adalah menunjukan jati diri mereka sebagai etnis yang mengembangkan kebudayaan yang tidak bisa lepas dari hutan. Sebutan ini adalah yang paling proporsional dan obyektif karena didasarkan kepada konsep Orang Rimba itu sendiri dalam menyebut dirinya. ${ }^{5}$

\footnotetext{
3 . Profil Komunitas Adat Terpencil (Kat) Dan Program Pemberdayaan KAT Di Provinsi Jambi Oleh Dinas Sosial Tenaga Kerja Dan Transmigrasi Provinsi JambiTahun 2013.

4 .ibid.

${ }^{5}$.ibid
} 


\section{Asal Usul Suku Anak Dalam ( SAD )}

Suku Anak Dalam merupakan salah satu komunitas adat terpencil yang ada di Provinsi Jambi. Menurut Muchlas (1975) tentang"Kehidupan Suku Anak Dalam" menyebutkan ;

- Anak Dalam artinya rakyat pedalaman

- Kubu artinya bertahan atau pertahanan maka Orang Kubu artinya orang yang menghasilkan diri atau orang yang bertahan.

Tentang asal usul Suku Anak Dalam (SAD) (Muchlas, 1975) menyebutkan bermacam crita/hikayat dari penuturan lisan yakni : Cerita Buah Gelumbang, Tambo Anak Dalam (Minang Kabau), Cerita Orang Kayu Hitam, Cerita Seri Sumatra Tengah, Cerita Perang Bagindo Ali, Cerita Perang Jambi dengan Belanda, Cerita Tambo Sriwijaya, Cerita Turunan Ulu Besar dan Bayat, cerita tentang Orang Kubu.

Dari hakikat / cerita tersebut Muchlas menarik kesimpulan bahwa Suku Anak Dalam berasal dari tiga keturunan “

1. Keturunan dari Sumatera Selatan, umumnya tinggal di Wilayah Kabupaten Batang Hari.

2. Keturunan dari Minang Kabau, umumnya di Kabupaten Bungo, Kabupaten Tebo sebagian Mersam Kab. Batang Hari.

3. Keturunan dari Jambi asli yaitu Kubu Air Hitam Kabupaten Sarolangun Bangko (Muchlas, 1975)."6

Versi Departemen Sosial dalam data dan informasi Depsos RI (1990) menyebutkan asal-usul Suku Anak Dalam (SAD) yakni : sejak tahun 1624 Kesultanan Palembang dan Kerajaan Jambi, yang sebenarnya masih satu rumpun, memang terus menerus berisi tegang dan pertempuran di Air Hitam akhirnya pecah pada tahun 1929, versi ini menunjukan mengapa pada saat ini ada 2 (dua) kelompok masyarakat

Anak Dalam dengan bahasa, bentuk fisik, tempat tinggal dan adat istiadat yang berbeda. Mereka yang menempati belantara Musi Rawas (Sumatera Selatan) berbahasa melayu, berkulit kuning dengan berpostur tubuh ras Mongolid seperti orang Palembang sekarang; Mereka keturunan pasukan Palembang. Kelomok lainnya tinggal dikawasan hutan Jambi berkulit sawo matang, rambut ikal, mata menjorok kedalam, mereka tergolong ras Wedoid (campur wedda dan negrito). Konon mereka tentara bayaran Kerajaan Jambi dari Negara lain.

Versi lain adalah cerita tentang Perang Jambi dengan Belanda yang berakhir pada tahun 1904, pihak pasukan Jambi yang dibela Anak Dalam yang dipimpin oleh Raden Perang. Raden Perang adalah seorang cucu dari Raden Nagasari. Dalam perang gerilya maka terkenalah Anak Dalam dengan sebutan Orang Kubu artinya orang yang tak mau menyerah pada penjajahan Belanda yang membawa penyakit

${ }^{6}$ Ibid 
jauh senjata api. Orang Belanda disebutnya orang kayo putih sebagai lawan Raja Jambi (Orang Kayo Hitam) (Muchlas 1995). ${ }^{7}$

Lebih lanjut tentang asal-usul "Suku Anak Dalam" ini juga dimuat pada seri Profil Masyarakat Terasing (BMT, Depsos, 1988) yakni sebagai berikut :

Pada zaman dahulu kala terjadi peperangan antara kerajaan Jambi dipimpin oleh Putri Selaras Pinang Masak dan Kerajaan Tanjung Jabung dipimpin oleh Rangkayo Hitam. Peperangan ini semakin berkobar akhirnya didengar oleh Raja Pagar Ruyung, yaitu ayah dari Putri Selara Pinang Masak untuk menyelesaikan peperangan tersebut Raja Pagar Ruyung mengirimkan prajurit-prajurit yang gagah berani untuk membantu kerajaan Jambi yang dipimpin oleh Putri Selaras Pinang Masak. Raja Pagar Ruyung memerintah agar dapat menaklukan Kerajaan Rangkayo Hitam, mereka menyanggupi dan bersumpah /berjanji tidak akan kembali sebelum menang.

Jarak antara kerajaan Pagar Ruyung dengan Kerajaan Jambi sangat jauh, harus melalui hutan rimba belantara dengan jalan kaki. Perjalanan mereka sudah berharihari lamanya, Kondisi mereka sudah mulai menurun sedangkan persediaan bahan makanan sudah habis, mereka kebingungan sementara perjalanan masih jauh, untuk kembali ke kerajaan Pagar Ruyung mereka merasa malu. Sehingga mereka bermusyawarah untuk mempertahankan diri hidup dalam hutan. Untuk menghindarkan rasa malu merekamencari tempat-tempat sepi jauh kedalam rimba raya. Keadaan hidup mereka makin lama makin terpencil, keturunan mereka menamakan dirinya Suku Anak Dalam.

Dari uraian diatas sejalan dengan yang dikemukakan (Koentjaraningrat, 1993) bahwa asal mula adanya masyarakat terasing dapat dibagi dua yaitu ; Pertama dengan menganggap bahwa masyarakat terasing itu merupakan sisa-sisa dari suatu produk lama yang tertinggal di daerah-daerah yang tidak dilewati penduduk sekarang. Kedua bahwa mereka merupakan bagian dari produk sekarang yang karena pristiwa-pristiwa tertentu diusir atau melarikan diri ke daerah-daerah terpencil sehingga mereka tidak mengikuti perkembangan dan kemajuan penduduk sekarang.

Tentang Suku Anak Dalam (orang rimba) Ruliyanto, wartawan Tempo (Tempo, April 2002) menulis bahwa; Sejumlah artikel terakhir menyebutkan Orang Rimba merupakan kelompok melayu tua lainnya di Indonesia seperti orang Dayak, Sakai, Mentawai, Nias, Toraja, Sasak, Papua, dan Batak pedalaman. Kelompok Melayu Tua merupakan eksodus gelombang pertama yunani (Dekat lembah sungai yang tze di Cina Selatan) yang masuk ke Indonesia Selatan tahun 2000 sebelum Masehi. Mereka

\footnotetext{
${ }^{7}$ lbid.
} 
kemudian tersingkir dan lari kehutan ketika kelompok melayu muda datang dengan mengusung peradaban yang lebih tinggi antara tahun 2000 dan 3000 sebelum Masehi.

Menurut Van Dongen (19060 dalam Tempo (2002) menyebutkan bahwa Orang Rimba sebagai orang primitive yang taraf kemampuannya masih sangat rendah dan tidak beragama dalam hubungannya dengan dunia luar orang rimba memperaktekan silent trade mereka melakukan transaksi dengan bersembunyi didalam hutan dan melakukan barter, mereka meletakannya dipinggir hutan kemudian orang melayu akan mengambil dan menukarnya. Gong-gongan anjing merupakan tanda barang telah ditukar. Senada dengan Bernard Hagen (1908) dalam Tempo (2002) (dia orang kubu of Sumatra) menyatakan orang rimba sebagai orang pra melayu yang merupakan penduduk asli Sumatra demikian pula Paul Bescrta mengatakan bahwa orang rimba sama dengan foto orang melayu (melayu tua) yang ada di semenanjung Melayu yang terdesak oleh kedatangan Melayu Muda ${ }^{8}$.

\section{Tindakan Pemerintah Daerah dalam memberikn perlindungan Hukum terhadap Suku Anak Dalam}

Pemerintah atau administrasi Negara adalah sebagai subjek hukum atau pendukung hak dan kewajiban. Sebagai subjek hukum pemerintah melakukan berbagai tindakan baik tindakan nyata( feeitelijkhandelingen ) maupun tindakan hukum ( rechtshandelingen). Tindakan nyata adalah tindakan -tindakan yang tidak ada relevansinya dengan hukum dan oleh karenanya tidak menimbulkan akibat akibat hukum . Sedangkan tindakan nyata menurut Huisman, tindakan tindakan yang berdasarkan sifatnya dapat menimbulkan akibat hukum tertentu (een rechthandelingen is gericht op het scheppen van rechten of plichten ) atau tindakan hukum adalah tindakan yang di maksudkan menimbulkan untuk menciptakan hak dan kewajiban. ${ }^{9}$

Dalam bidang hukum perdata tindakan hukum merupakan tahab awal lahirnya hubungan hukum (rechtsbetreckking) yaitu suatu hubungan yang ada relevansi dengan hukum atau hubungan yang dapat menimbulkanhak dan kewajiban. Hubungan hukum dalam perdata ini lahir adanya kehendak kedua belah pihak dan pernyataan kehendak antara pihak pihak dalam kedudukan yang sejajar. Istilah tindakan hukum yang berasal dari ajaran hukum perdata ini digunakan dalam hukum administrasinegara sehingga dikenal dengan istilah hukum tindakan hukum administrasi. ${ }^{10}$ Menurut Romeijn, tindakan hukum administrasi adalah suatu pernyataan kehendak yang muncul dari organ administrasi dalam keadaan khusus dimaksudkan untuk menimbulkan akibat hukum dalam bidang hukum administrasi, akibat hukum itu dapat berupa:

\footnotetext{
8

${ }^{9}$ Ridwan HR, Hukum Administrasi Negara, penerbit UII Pres Jogyakarta 2002.

10 .ibid hal 82
} 
1. Perubahan hak, kewajiban, atau kewenangan yang ada

2. Menimbulkan perubahan kedudukan hukum bagi seseorang atau objek yang ada

3. Bilamana terdapat hak -hak dan kewajiban,kewenangan ataupun status tertentu yang ditetapkan. ${ }^{11}$

Dihubungkanndengan permasalahan yang diteliti tentang bagaimana tindakan pemerintah daerah dalam memberikan perlindungan hukum terhadap suku anak dalam yang berkeliaran yang mengemis di Kota Jambi. Sesuai dengan konsep dari tindakan pemerintah yang terdiri dari tindakan nyata dan tindakan hukum bahwa pemerintah daerah seuai dengan kewenangan yang diberikan oleh Undang -undang yang berdasarkan kepada sumber kewenangan delegasi . bahwa dalam memberi perlindungan hukum ini adalah kewenangan pemerintah propinsi yang didelegasikan kepada Dinas Sosial, Administrasi Kependudukan dan Pencatatan Sipil Provinsi Jambi. Yang di bentuk berdasarkan Peraturan Daerah Provinsi Jambi Nomor 8 Tahun 2016 Tentang Pembentukan Dan Susunan Perangkat Daerah Provlnsi Jambi.

Berdasarkan Keputusan Gubernur Jambi Nomor 360/Kep.Gub./Sosnakertrans/2014 Tentang Penetapan Kelompok Kerja komunitas Adat Terpencil Provinsi Jambi.kelompok kerja sebagaimana yang dimaksud dalam Keputusan Gubernur memepunyai tugas mengsingkronisasikan dan mengkoordinasi kegiatan perencanaan ,pelaksanaan,pemantauan ,evaluasi dan pelaporan pemberdayaan kesejahteraan social komonitas adat terpencil.

Yang menjadi pertanyaan dalam dictum mengingat dari Keputusan Gubernur nomor 360/Kep.Gub/nakertrans/2014 tidak ada Peraturan Daerah Provinsi Jambi atau Peraturan Gubernur Provinsi Jambi sebagai dasar hukum dikeluarkannya Keputusan Gubernur.

Berdasarkan keputusan Gubernur tersebut di atas bahwa Provinsi Jambi sudah menyususun program program dalam pembinaan suku anak dalam dengan tujuan memberikan perlindungan terhadap mereka. Pemberdayaan KAT tepat sasaran, tepat waktu, dan tepat guna sesuai dengan aspirasi warga yang akan diberdayakan. Calon lokasi sebaran warga Komunitas Adat Terpencil (KAT) Suku Anak Dalam yang akan diberdayakan pada tahun I sampai Tahun III ditetapkan di satu Kabupaten atau lebih sesuai dengan hasil kegiatan Studi Kelayakan yang telah dilaksanakan. Program penanggulangan kemiskinan ini terdiri dari dua kegiatan yaitu :

\section{Pemberdayaan Tahun I}

Kegiatan ini adalah membangun sarana pemukiman Warga Komunitas Adat Terpencil (KAT) yang telah melewati proses PCLP pada tahun sebelumnya oleh Tim dan dinyatakan memnuhi syarat untuk diberdayakan yang diperkuat oleh

\footnotetext{
${ }^{11}$ Ibid hal 83
} 
rekomendasi dari Bupati. Kegiatan pemberdayaan tahun I dilaksanakan di lokasi warga KAT tinggal (metode insitu). Jenis kegiatan yang dilaksanakan pada Pemberdayaan tahun I adalah ;

Penyiapan pembukaan lahan perumahan, pembangunan rumah sederhana untuk warga KAT ukuran type 36, pembangunan pasilitas umum balai social type 120 sebanyak, , pembangunan sarana air bersih dan MCK, pembuatan jalan lingkungan gol 4 panjang, pemberian jaminan hidup untuk warga selama 8 bulan dalam bentuk Paket, bantuan peralatan kerja rumah tangga, bantuan peralatan kerja, dan pemberian bibit tanam palawija dan pupuk yang disesuaikan dengan kondisi lingkungan setempat.

\section{Pemberdayaan Tahun II}

Kegiatan program pemberdayaan tahun ke-II adalah kegiatan yang bersipat bimbingan mental spiritual dan perubahan sikap, bimbingan keterampilan pertanian (UPAJIWA), pembenahan catatan kependudukan, pemberian jadup selama 9 bulan, dan dan sarana penerangan.

\section{Pemberdayaan Tahun III}

Kegiatan bersifat Ekonomi Warga KAT, dengan kegiatan yaitu pemberian bantuan modal usaha ekonomi produktif. Kegiatan Kelompok Usaha Bersama, yang disesuaikan dengan kemampuan keterampilan warga. Aplikasi pengembangan potensi usaha ekonomis produktif untuk memantapkan program menghapuskan kemiskinan tentunya Warga Komunitas Adat Terepencil (KAT) merupakan bagian dari penyandang masalah kemiskinan. Dengan bantuan tersebut diharapkan Warga KAT dapat mempercepat ketertinggalan mereka dalam berbagai aspek kehidupan dan penghidupan sehingga kesejahteraan sosialnya dapat segera meningkat.

Melalui kegiatan ini Warga Komunitas Adat Terepencil (KAT) diharapkan akan dapat mengembangkan potensi usaha ekonomis produktif yang ada di lingkungan mereka, dan untuk lebih memperkuat satabilisasi kehidupan yang menetap maka pada ke III lahan Perumahan dan pekarangan warga disertifikatkan bekerja sama dengan BPN Provinsi dan Kabupaten. ${ }^{12}$

Berdasarkan program yang sudah di buat oleh Dinas Sosial Kependudukan dan Nakertrans Provinsi Jambi pada prinsip nya pemerintah daerah sudah berupaya untuk melakukan tindakan nyata tetapi untuk merealisasi program tersebut harus

\footnotetext{
12 Profil Komunitas Adat Terpencil (Kat) Dan Program Pemberdayaan Kat Di Provinsi Jambi, Dinas Sosial Kependudukan dan Nakerstrans Provinsi Jambi , 2017
} 
berdasarkan peraturan daerah dan diiringi dengan peratutan gubernur sebagai petunjuk teknis dalam pelaksanaan program.

Mengapa program yang di susun oleh DinsosDukCapil Nakertrans Provinsi Jambi harus di laksanakan berdasarkan peraturan daerah karena berdasarkan salah satu asas pembentukan peraturan perundang - undangan, apabila kegiatan yang di lakukan mengatur kepentingan orang banyak harus dilaksanakan berdasarkan produk hukum. Produk hukum harus sesuai dengan kewenangan yang diberikan, bahwa perlindungan suku anak dalam ini merupakan kewenangan dari pemerintah daerah maka dalam pelaksanaan program yang di susun oleh DinsosDuk Capil Nakertrans harus berdasarkan Perda, sebagai tindakan hukum dari perbuatan pemerintah daerah.

\section{KESIMPULAN DAN SARAN}

Suku Anak Dalam yang mencari kehidupan di Kota Jambi adalah sebagai akibat lahan tempat mereka mencari nafkah semangkin hari semangkin meneipis karena banyaknya izin dalam pengelolaan hutan yang yang di keluarkan oleh pemerintah, sehingga komonitas mereka semankin tersingkir dari kehidupan mereka selama ini.

Pemerintah Provinsi Jambi memberikan kewenangan kepada Dinas Sosial, Administrasi Kependukan dan Catatan Sipil Provinsi Jambi sebagai realisasi tindakan pemerintah yang merupakan tindakan nyata sudah berusaha membuat program dalam pembinaan suku anak dalam. Tetapi dalam pelaksanaan nya program ini tidak berjalan secara kontiniu karena keterbatasan anggaran. Tindakan hukum pemerintah daerah Provinsi Jambi yang di wujudkan dalam bentuk Perda sampai saat saat penelitian ini berakhir bahwa pemerintah Daerah Provinsi Jambi belum membuat peraturan daerah yang merupakan payung hukum dalam rangka perlindungan terhadap suku anak dalam maupun perlindungan terhadap hak hak konstitusi mereka.

\section{DAFTAR PUSTAKA}

Utrecht. E Pengantar Hukum Administrasi Negara Indonesia,Fakultas Hukum

Dan Pengetahuan Masyarakat Universitas Padjadjaran..Bandung,1960.

Ridwan.HR Hukum Administrasi Negara.Rajawali Pers.Jakarta.2011

Bagir.Manan, Menyongsong Pajar Otonomi Daerah, Pusat Studi Hukum Fakultas

Hukum Universitas Islam Indonesia.Yogyakarta.2001

Marzuki Mahmud. Metode Penelitian Hukum. Surabaya.2011

Salim, Dasar-Dasar Hukum Kehutanan. Jakarta.2008 
Supriadi, Hukum Kehutanan dan Hukum Perkebunan di Indonesia,Jakarta. Sinar Grafika.2010

Sukamto Satoto, Pengaturan Eksistensi \& Fungsi Badan Kepegawaian Negara, Cet I, Penerbit CV. Hangar Kreator, Jogjakarta, 2004.

Sinambela, Lian Poltak, Reformasi Pelayanan Publik, Cet I, Penerbit PT. Bumi Aksara, Jakarta, 2006.

Profil Komunitas Adat Terpencil (Kat) Dan Program Pemberdayaan KAT Di

Provinsi Jambi Oleh Dinas Sosial Tenaga Kerja Dan Transmigrasi Provinsi JambiTahun 2013

Undang-undang Dasar Negara Republik Indonesia 1945 Amandemen.

Undang-Undang Nomor 32 Tahun 2004 Tentang Pemerintah Daerah.

Undang-undang Nomor 32 Tahun 2009 Tentang Perlindungan,Pengelolaan Lingkungan Hidup.

Undang Undang Nomor 26 Tahun 2007 Tentang Penataan Ruang

,Peraturan Pemerintah Nomor 34 Tahun 2002 Tentang Tata Hutan

Dan Penyusunan Rencana Pengelolaan Hutan, Pemanfaatan Hutan Dan Penggunaan Kawasan Hutan.

Peraturan Daerah Nomor 06 Tahun 2009 Tentang Hutan Kota. 